\title{
Physicochemical Properties and Acceptability of Gluten-Free Biscuits as Affected by some Cereals and Tubers Type
}

\author{
Mohamed E. Salem*; Fatma M. El-Zayet; Ahmed M. Rayan and Adel A. Shatta \\ Food Technology Department, Faculty of Agriculture, Suez Canal University, Ismailia, PC 41522, Egypt
}

Received: $17 / 1 / 2019$

\begin{abstract}
In recent years, there has been an increase in demand of gluten-free products that are suitable for people with coeliac disease.The coeliac disease occurs when the body's natural defense system reacts to gluten, a wheat protein by attacking the lining of the small intestine.There is no medication of this disease instead of using gluten-free food. Moreover, coeliac patients use foods with low fiber with poor quality, hence generally face the problems of constipation and malnutrition. The current study aimed to produce gluten-free biscuits from cereals flour alone or composite with tubers flour to use it in coeliac disease cases nutrition. Gluten free-biscuits developed with rice (RF), quinoa (QF), amaranth (AF), soybean (SF), taro (TF), sweet potato (SPF) and potato (PF) flours using standard method. Nineteen experimental variants (aglutenics biscuits) were obtained by varying the proportion of flours. The biscuits produced were subjected to proximate composition, physical and sensory evaluations using standard methods. Results showed that biscuits produced with rice, quinoa, amaranth, and composite flours had low moisture content $(<5 \%)$ and protein up to $10.67 \%$, crude fat (18.48-22.61\%), ash (0.51-2.35\%), crude fiber (0.23-2.64\%), total carbohydrates $(65.03-73.60 \%)$ as well as energy value $(480-504 \mathrm{Kcal} / 100 \mathrm{~g})$ according to the blend ingredients. Sensory evaluation showed that biscuits produced from rice (100\%), rice: quinoa: amaranth (40:30:30), and rice: amaranth (50:50) are the most acceptable biscuits in terms of taste, color, crispness, appearance and consumer preference acceptability which differs significantly $(\mathrm{p} \leq 0.05)$ from all the biscuit produced from rest blends. Therefore, it can be concluded that aglutenics biscuits, rice 100\%, Developed with RF $50 \%$ : QF 50\%, RF 40\%: QF 30\%: AF 30\% and RF 50\%: AF 50\% are more suitable for consumption.
\end{abstract}

Keywords: Aglutenics biscuits, proximate composition, composite flour, physical properties, sensory evaluation

\section{INTRODUCTION}

Nowadays, increasing consumers' interest in healthier nutrition constrains food industry to extend offered assortment about products with increasing portion of fiber, vitamins, minerals etc. (Vega-Gálvez et al., 2010). In recent years, there has been an increase in demand of gluten-free products that are suitable for people with coeliac disease (Aly and Seleem, 2015).

Coeliac disease (CD), a common autoimmune enteropathy elicited following gluten ingestion in patients with a genetic predisposition, affects approximately $1 \%$ of the general population although this percentage is probably an underestimation since the condition often being left undiagnosed (Sapone et al., 2012). Coeliac disease patients (children and adolescents) when consume food containing gluten, their immune system responds by damaging the intestinal villi leading to the mal-absorption of nutrients, which in turn adversely affect all the systems of the body (Noor et al., 2012). The only remedy of this disease is to consume gluten-free diet. Gluten-free food stuffs are food similar in appearance to congenital food, which is consumed as a part of usual diet but reduces the risk of chronic disease (coeliac disease) beyond basic nutrition functions. The gluten-free food market has been shown a big grow in the last years, evidencing an annual rate of $28 \%$ (Kaur et al., 2014).

Gluten-free foods are generally low in fiber, protein, vitamins with minimal mineral content and contain pure starch, which gives sandy, dry mouth-feel with poor sensory attributes (Okpala and Okoli, 2011). Moreover, it is considered nutritionally poor, as cereal proteins are deficient in essential amino acids such as lysine and threonine (Dhingraand Jood, 2001). This circumstance has prompted the development of glutenfree foodstuffs with high nutritional quality components (De-La Barca et al., 2010; Majzoobi et al., 2016). In general, gluten-free baked goods comprises several raw materials like rice, corn, buckwheat, cassava and potato starches and/or flours (Sciarini et al., 2012). At present, crops like amaranth, teff and quinoa which are comparatively novel or lesser known on the gluten-free market are offered (Doporto et al., 2017).

Unfortunately, gluten-free food items are not available easily in the shelves especially in developing countries and are expensive (Javaria et al., 2017). Many efforts have been carried out to promote the use of flour blends, in which a portion of rice flour is replaced by locally grown crops thereby decreasing the cost associated with imported the gluten-free products in Egypt.

Biscuits are famous food product consumed by an extensive variety of consumers as breakfast items and as snacks because of their different taste, long time span of usability and low cost (Javaria et al., 2017). The major constituents are typically wheat flour, sucrose and fat, making biscuits a rather energy dense cereal food (Sozer et al., 2014). By altering the ratio of different flours other than wheat and adding up different nutritive ingredients may improve the quality and shelf-life of biscuits (Ahmed et al., 2012). All biscuits are nutritionals, contributing valuable quantities of iron, calcium, protein, calorie, fibre and some of the Bvitamins to our diet and daily food requirement. Composite flour has the added advantage of improving the nutrient value of biscuits and other bakery products 
especially when cereals are blended with legumes or tubers (Tyagi et al., 2007).

The utilization of rice, quinoa, amaranth as well as tubers flours (taro, sweet potato and potato) blends in the production of baked product such as biscuits can serve as an alternative means of diversifying the use of non-wheat flour (gluten-free flours). These flour blends have the potential to increase the nutritional value of biscuits, enhance food security and reduce wheat importation thereby increase the farmers' income. Applications of flours from their crops in the manufacture of gluten-free biscuits will also increase the taste variants of gluten-free biscuits, which is quite limited in Egypt.Therefore, the objective of this study was to assess the chemical compositions, physical and sensory properties of biscuits produced from rice, quinoa, amaranth and composite tubers flour blends.

\section{MATERIALS AND METHODS}

\section{Materials:}

Rice, taro, sweet potato, potato and extruded soybean seeds used for the study were purchased from local market in Ismailia Governorate, Egypt. Quinoa and amaranth seeds were obtained from farm in Suez Governorate, Egypt during the season 2016 - 2017.

Ingredients used for biscuits production (shortening, sugar, leaving agent, eggs and vanilla powder) were also purchased from local market in Ismailia. All chemicals used for the analysis were of Analar grade purchased by Food Technology Department, University of Suez Canal, Ismailia, Egypt from Aldrich/Sigma, USA.

\section{Preparation of flours:}

Preparing rice, amaranth and extruded soybean into flours:

Rice, amaranth and extrudedsoybean seeds were manually sorted to remove imparities and ground by a laboratory mill (Brabender Automat Mill Quandrumat Senior, Germany) to obtain homogeneous granules and screened through a $150 \mu \mathrm{m}$ sieve (Danbaba et al., 2016). The flours were packed in high density polyethylene bags, heat sealed and then stored in freezer until used.

\section{Quinoa flour preparation:}

The seeds were harvested, cleaned and then washed with cold/hot water several times to remove saponins until there was no more foam in the washing water (Atef et al., 2014). The seeds were sun-dried and then ground to fine powder by a laboratory mill (Brabender Automat Mill Quandrumat Senior, Germany), sifted through a $150 \mu \mathrm{m}$ sieve. The flours were packed in high density polyethylene bags, heat sealed and then stored in freezer until used in technological studies.

\section{Preparation of taro, sweet potato and potato flours:}

The tubers (roots) were cleaned of sand, peeled manually, washed and cut into uniform sized slices with a sharp stainless knife. The slices were blanched at $100^{\circ} \mathrm{C}$ for $5 \mathrm{~min}$ to control enzymatic browning then dried in hot-air oven $\left(60^{\circ} \mathrm{C} / 12 \mathrm{~h}\right)$ (Van Toan and Thanh, 2018). The dried slices were milled using laboratory mill (Brabender Automat Mill Quandrumat Senior, Germany) to obtain homogeneous granules and sieved through a $150 \mu \mathrm{m}$ pore size sieve to obtain the fine flour. The flours were packed in high density polyethylene bags, heat sealed and then stored in freezer until used.

\section{Blends preparation and experimental plan:}

All flours were blended with others according to Table 1. Nineteen blends were stored in airtight containers and kept at $4^{\circ} \mathrm{C}$ until required.

The ingredients for $100 \mathrm{~g}$ flour used in the preparation of biscuits are tabulated in Table 2.

Table (1): Formulation of flour blends (\%) for biscuits production

\begin{tabular}{|c|c|c|c|c|c|c|}
\hline RF & $\mathbf{Q F}$ & $\mathbf{A F}$ & SF & TF & SPF & $\mathbf{P F}$ \\
\hline \multicolumn{7}{|c|}{ Flour blends } \\
\hline 100 & - & - & - & - & - & - \\
\hline 50 & - & - & 20 & - & 30 & - \\
\hline 50 & - & - & 20 & 30 & - & - \\
\hline 50 & - & - & 20 & - & - & 30 \\
\hline- & 100 & - & - & - & - & - \\
\hline- & 50 & - & 20 & - & 30 & - \\
\hline- & 50 & - & 20 & 30 & - & - \\
\hline- & 50 & - & 20 & - & - & 30 \\
\hline- & - & 100 & - & - & - & - \\
\hline- & - & 50 & 20 & - & 30 & - \\
\hline- & - & 50 & 20 & 30 & - & - \\
\hline- & - & 50 & 20 & - & - & 30 \\
\hline 50 & 50 & - & - & - & - & - \\
\hline 50 & - & 50 & - & - & - & - \\
\hline- & 50 & 50 & - & - & - & - \\
\hline 40 & 30 & 30 & - & - & - & - \\
\hline 20 & 15 & 15 & 20 & - & 30 & - \\
\hline 20 & 15 & 15 & 20 & 30 & - & - \\
\hline 20 & 15 & 15 & 20 & - & - & 30 \\
\hline
\end{tabular}

Rice flour (RF), Quinoa flour (QF), Amaranth flour (AF), Soybean flour (SF), Sweet potatoflour (SPF), Taro flour (TF) and Potato flour (PF)

Table (2): Ingredients of biscuits production

\begin{tabular}{lc} 
Ingredient & $\begin{array}{c}\text { Calculated for 100g } \\
\text { flour }\end{array}$ \\
\hline Sugar & $33 \mathrm{~g}$ \\
Shortening & $28 \mathrm{~g}$ \\
Ammonium bicarbonate & $0.35 \mathrm{~g}$ \\
Sodium bicarbonate & $0.45 \mathrm{~g}$ \\
Egg (fresh) & $20 \mathrm{~g}$ \\
Vanilla powder & $0.25 \mathrm{~g}$ \\
Water & $30-35 \mathrm{ml}$ \\
\hline
\end{tabular}




\section{Production of biscuits:}

The biscuits were produced using creaming method described by Abd El-Hady (2002) and Man et al. (2014) with some modifications. The dough was prepared in a laboratory dough mixer. Shortening and ground sugar were mixed in a mixer with a flat beater for $10 \mathrm{~min}$ at high speed until the mixture became light. Eggs were added wile mixing continuously. The flour along with leavening agents and vanilla were taken in the bowl of dough mixer for $10 \mathrm{~min}$ to obtain firm dough and dough was prepared using appropriate amount of water. The dough after mixing was transferred to the biscuits making machine (thickness $5.28 \mathrm{~mm}$, diameter $35.82 \mathrm{~mm}$ ). The dough pieces were transformed onto a baking tray lined with aluminum foil.Biscuit dough were baked at $220^{\circ} \mathrm{C}$ for $10 \mathrm{~min}$. Biscuits were allowed to cool for $40 \mathrm{~min}$ at room temperature $\left(29 \pm 2^{\circ} \mathrm{C}\right)$ and packaged in polyethylene bags, then held at room temperature for evaluation.

\section{Methods of analysis:}

Determination of proximate composition and caloric value of the resultant gluten-free biscuits:

The moisture, crude protein, crude fat, ash and crude fiber were determined according to AOAC (2010). Total carbohydrates (on a dry weight basis) was obtained by difference; while gross energy (calorific values) was calculated by multiplying the values of crude protein, fat and carbohydrate by their respective physiological fuel value of 4,9 and 4 , respectively in Kilocalories per a hundred gram of sample (Kcal/100g) as described by Bello et al. (2018). All analyses were performed in triplicate.

\section{Determination of physical properties of biscuits:}

The methods described by Adeola and Ohizua (2018) were used with a slight modification to evaluate the biscuit for the following parameters: Thickness of biscuits was determined with a Digital Caliper. The experiment was replicated ten the mean was recorded and expressed in millimeter. Diameter of biscuits was determined by placing four biscuit samples edge to edge and measuring with a digital caliper. An average of ten values was taken for each set of samples. Average value for diameter was reported in millimeter. Spread ratio was calculated by dividing diameter/thickness (Mc Watters et al., 2003).

Hardness of the biscuit samples was determined using Barabender Struct-O-Graph (Model No.8603, OHG, Dusburg, Germany) according to the method described by AACC (2002). Barabender units (BU) were converted to Newton according to Morsy et al. (2015). Ten measurements were recorded for each sample.

\section{Determination of color attributes of gluten -free biscuits:}

Color values of both top and bottom surface of biscuits samples were determined by Minolta Chroma meter CR-400 (Minolta Camera Co., Ltd., Osaka, Japan) in the reflection mode. Five replicates of each biscuit type were measured from ten different locations. The parameters determined were $L^{*}\left(L^{*}=0\right.$ (black), $L^{*}=$
100 (white)), $a^{*}\left(-a^{*}=\right.$ greenness, $+a^{*}=$ redness $), b^{*}(-$ $b^{*}=$ blueness, $+b^{*}=$ yellowness $)$. Chroma $\left(C^{*}\right)$ is the attribute that allows the degree of difference in comparison to a grey color of the same lightness to be determined for each hue, so it considered the quantitative attribute of colorfulness. Whiteness Index (WI) was expressed as: WI $=100-\left[\left(100-L^{*}\right)^{2}+a^{* 2}+\right.$ $\left.b^{* 2}\right]^{0.5}$ (Bolin and Huxsoll, 1991).

The browning index (BI) (Buera et al., 1985) was calculated using the following equations:

$$
\begin{aligned}
& X=\frac{a *+1.75 L *}{5.645 L *+a *-3.012 b *} \\
& B I=\frac{100(x-0.31)}{0.172}
\end{aligned}
$$

\section{Sensory evaluation of the resultant biscuits:}

Sensory characteristics of biscuits samples from various flour blends were evaluated for different sensory attributes by sixteen (16) semi trained panelists drawn from the Department of Food Technology, University of Suez Canal, Ismailia, Egypt. The test was conducted while the samples were still fresh. All the panelists were briefed before the commencement of the evaluation process. Sensory attributes evaluated were taste, color, texture, appearance, and acceptability (consumer preference) (Meilgaard et al., 2007). Hedonic scale was in the following sequence: like extremely -9 , like very much -8 , like moderately- 7 , like slightly -6 , neither like nor dislike-5, dislike slightly-4, dislike moderately,-3, dislike very much-2, dislike extremely - 1 (Mishra et al., 2015). All panelists were regular consumers of biscuits, water at room temperature was provided to rinse the mouth between evaluations.

\section{Statistical analysis:}

The data collected were subjected to analysis of variance (ANOVA). Means were separated using Duncan's Multiple Range Test using the statistical package for the social sciences (SPSS) ver. 20.00 (SPSS Inc., Chicago, IL, USA).

\section{RESULTS AND DISCUSSIONS}

\section{Proximate composition of the resultant biscuits:}

The resultant biscuits were divided into 4 classes: firstly, rice-based samples (100\% RF, 50\% RF: $30 \%$ SPF: $20 \%$ SF, 50\% RF: $30 \%$ PF: $20 \%$ SF and 50\% RF: $30 \%$ TF: $20 \%$ SF); secondly, quinoa based samples (100\% QF, 50\% QF: 30\% SPF: 20\% SF; 50\% QF: 30\% PF: $20 \%$ SF and 50\% QF: 30\% TF: 20\%SF); thirdly, amaranth-based samples (100\% AF, 50\% AF: $30 \%$ SPF: $20 \%$ SF, 50\% AF: $30 \%$ PF: $20 \%$ SF and 50\% AF: $30 \%$ TF: $20 \%$ SF) and fourthly, composite flour-based samples (50\% RF: 50\% QF), (50\% RF: 50\% AF), (50\% QF: $50 \%$ AF), (40\% RF: 30\% QF: 30\% AF), (20\% RF: 15\% QF: $15 \%$ AF: 30\% SPF: 20\% SF), (20\% RF: $15 \%$ QF: $15 \%$ AF: $30 \%$ PF: $20 \%$ SF) and (20\%RF: 15\% QF: 15\% AF: $30 \%$ TF: $20 \%$ SF) are presented in Table 3.

Proximate composition of rice biscuits and its blends:

Table (3) showed the proximate composition of RF biscuits and it's supplemented with SPF, PF, TF and 
SF. The moisture content increased from $2.63 \%$ (100\% RF) to $3.70 \%$ (50\% RF: $30 \%$ TF: $20 \% \mathrm{SF})$. The protein content increased from $6.13(100 \% \mathrm{RF})$ to $9.27 \%(50 \%$ RF: $30 \%$ TF: $20 \%$ SF). Same trend also in ash and crude fiber increased from 0.51 and $0.23 \%$ to 1.51 and $1.66 \%$, respectively. Conversely, the carbohydrates and fat contents decreased from 72.66 and $20.46 \%$ to 69.00 and $18.55 \%$ (50\% RF: $30 \%$ TF: $20 \%$ SF). Also, energy value decreased from 499.33 (100\% RF) to $480.06 \mathrm{kcal}$. /100g (50\% RF: $30 \%$ TF: 20\% SF). Total carbohydrates content was significantly higher than the quinoa $\left(2^{\text {nd }}\right.$ class) and amaranth ( $3^{\text {rd }}$ class) biscuitsamples.

In the case quinoa biscuits and its blends, Table 3 showed that the moisture content increased from 2.30 (100\% QF) to $4.03 \%$ (50\% QF: $30 \%$ TF: $20 \%$ SF). The protein content decreased from $10.67(100 \% \mathrm{QF})$ to 9.53\% (50\% QF: 30\% PF: $20 \%$ SF). The same trend in the case of crude fat content decreased from 22.61 (100\% QF) to $18.58 \%$ (50\% QF: $30 \%$ SPF: $20 \%$ SF). The ash and crude fiber contents increased from 0.69 and $1.53(100 \%$ QF) to 1.96 and $2.19 \%$ (50\% QF: $30 \%$ TF: $20 \%$ SF), respectively. Total carbohydrates increased from $64.50(100 \% \mathrm{QF})$ to $68.37 \%(50 \% \mathrm{QF}$ : $30 \%$ SPF: $20 \%$ SF). Conversely, the caloric value decreased from $504.16(100 \% \mathrm{QF})$ to $479.28 \mathrm{kcal} / 100 \mathrm{~g}$ (50\% QF: 30\% SPF: 20\% SF). Crude protein, fat and caloric values in quinoa based biscuits were significantly higher than all biscuit samples.

Regarding the amaranth biscuits and its blends, the moisture content increased from $3.43 \%$ (100\% AF) to $4.10 \%(50 \% \mathrm{AF}: 30 \% \mathrm{PF}: 20 \% \mathrm{SF})$. The protein content increased from $7.57(100 \% \mathrm{AF})$ to $9.31 \%(50 \%$ AF: $30 \%$ SPF: $20 \%$ SF). Also, the same trend for ash and crude fibre contents, increased from 1.43 and 1.92 (100\% AF) to 2.35 and $2.64 \%$ (50\% AF: $30 \%$ TF: $20 \%$ $\mathrm{SF})$. Conversely, crude fat, total carbohydrates and caloric values decreased from $22.22 \%, 66.86 \%$ and $497.73 \mathrm{Kcal} / 100 \mathrm{~g}(100 \% \mathrm{AF})$ to $20.00 \%$ (50\% AF: $30 \%$ PF: $20 \% \mathrm{SF}), 66.49 \%$ (50\% AF: $30 \%$ SPF: $20 \% \mathrm{SF})$ and $480.54 \mathrm{Kcal} / 100 \mathrm{~g}(50 \% \mathrm{AF}: 30 \% \mathrm{TF}: 20 \% \mathrm{SF})$, respectively.Crude fiber and ash contents were significantly higher than all rest resultant biscuits (Table $3)$.

In composite flour biscuits, Table 3 showed the proximate composition of composite flours biscuits $\left(4^{\text {th }}\right.$ class). The moisture content ranged from 2.90 (40\% RF: $30 \%$ QF: $30 \% \mathrm{AF}$ ) to $4.26 \%$ (20\% RF: $15 \%$ QF: $15 \%$ AF: $30 \%$ PF: $20 \%$ SF). The protein content ranged from 5.72 (50\% RF: $50 \%$ AF) to $9.53 \%$ (20\% RF: $15 \%$ QF: 15\% AF: $30 \%$ TF: $20 \%$ SF). The crude fat content ranged from 18.40 (50\% RF: $50 \% \mathrm{AF}$ ) to $20.29 \%(50 \%$ QF: $50 \%$ AF). The composite biscuits made from $50 \%$ RF: $50 \%$ QF and 20\% RF: $15 \%$ QF: $15 \%$ AF: $30 \%$ PF: $20 \%$ SF had 0.72 and 0.82 to 1.86 and $2.17 \%$ for ash and crude fiber contents, respectively. The total carbohydrates content ranged from 66.89 (20\% RF: 15\% QF: $15 \%$ AF: $30 \%$ TF: $20 \%$ SF) to $73.60 \%(50 \%$ RF: $50 \% \mathrm{AF})$. The caloric value ranged from 481.60 (20\% RF: $15 \%$ QF: $15 \%$ AF: $30 \%$ TF: $20 \%$ SF) to 487.24 Kcal/100g (50\% RF: 50\% QF).

From these results, the study was observed that moisture content in biscuits made from composite flours were significantly higher $(\mathrm{p} \leq 0.05)$ than that obtained for the rest resultant biscuits. Moisture content of the gluten-free biscuits was generally less than the 6\% (ES 416-1, 2013) required by the Egyptian Standard (ES) for plain biscuits (ES 416-1, 2013), which makes it desirable for long term storage. Low moisture content enhances the keeping properties of food products because it prevents the growth of micro-organisms. It also reduces the incidence of physical and chemical reactions that are likely to cause deterioration and lower quality (Akonor et al., 2017). The moisture content of the biscuit samples increased as the inclusion of sweet potato or potato or taro flours. This may be attributed to the high water-binding capacity of tubers flours, which retuned higher moisture content in the ultimate product (Anuonye et al., 2012; Adeola and Ohizua, 2018). Moreover, it is however interesting to note that moisture in all the products fell below $10 \%$ moisture. Moisture of $\leq 10 \%$ is said to play significant role in shelf life, packaging and general acceptability of products (Batista et al., 2016). In other words, moisture of $\leq 10$ is recommended for preservation of foods (Sanni et al., 2006). When compared with other studies, moisture obtained in the current study was lower than 4.61 6.34\% (Okudu and Ojinnaka, 2018) for biscuit produced from sorghum and watermelon seeds flour.

Protein in biscuit produced from quinoa flour and composite flour were significantly higher than that all rest resultant biscuits. Generally, gluten-free biscuits made from rice had lower protein content compared to quinoa and amaranth biscuits, which had the highest protein content. Protein content of rice biscuit could be increased incorporation of soybean (Table 3). Similar observations were observed by other authors (Anuonye et al., 2012; Fasoyiro and Arowora, 2013; Silky and Tiwari, 2014; Adeola and Ohizua, 2018).

Fat content of the gluten-free biscuits was quite (slight) high for biscuit made from the rice, quinoa, amaranth and composite flours (QF and AF) as well as blends of $50 \%$ QF: $30 \%$ TF or PF: $20 \%$ SF, $50 \%$ AF: $30 \%$ TF or PF: $20 \% \mathrm{SF}$, significant differences $(p \leq$ $0.05)$ were observed in fat content. The fat content of the biscuits did not appear to vary much as the same quantities of fat were added. The variations observed in the fat contents of the biscuit samples, despite the some quantity of fat used in the recipe, may be due to variations in their moisture content. This implies that developing products from rice using high $\mathrm{QF}$ and $\mathrm{AF}$ ratio could actually increase protein level while reducing that of fat. This finding could be of interest to nutritionist and dieticians particularly in area of complementary food formulation. Higher fat value seen in $100 \% \mathrm{QF}$ and $100 \% \mathrm{AF}$ samples relative to the produces could be a function of its oil absorption capacity. Lower fat found in biscuit with higher SPF and PF content is great importance as product with low fat known to have longer shelf-life. High fat in any product is known to promote rancidity (Okudu and Ojinnaka, 2018). The fat content of the biscuit was within the standard value (15-20\%) for soft dough biscuits (Manley, 2001). Similar values (15.1-18.1\%) were reported by other workers (Chinma et al., 2012; 
Asif-UI-Alam et al., 2014; Silky and Tiwari, 2014; Adeola and Ohizua, 2018) for biscuits prepared from composite flours containing different proportions of unripe banana flour, millet, wheat and tiger nut.

Total ash reflects the mineral content of food products and can be regarded as the general measure of quality (Akonor et al., 2017). It is often a useful criterion in identifying the authenticity of food product. The high ash contents of the biscuit samples attest to nutritional report that potato, taro, and sweet potato are good sources of calcium, sodium, magnesium, potassium and iron (Torres et al., 2007, Sharoba et al., 2014; Adeola and Ohizua, 2018). Compared to the others biscuits made from composite flour $(50 \%$ AF: $30 \%$ TF: $20 \%$ SF) was observed to have the highest amount of ash $(2.35 \%)$. This indicates that biscuit from this composite flour may contain high amounts of minerals. For the various kinds of flours, significant differences $(\mathrm{p} \leqq 0.05)$ in ash content were recorded from one substitution level (50\% AF: $30 \%$ TF or PF: $20 \%$ SF) to the others (Table 3).

Table (3): Proximate composition (g/100g, dry basis) and calories (Kcal/100g) of gluten free biscuits produced from rice, quinoa and amaranth flours with some tuber flours

\begin{tabular}{|c|c|c|c|c|c|c|c|}
\hline Biscuit samples & Moisture & Protein & $\begin{array}{c}\text { Crude } \\
\text { fat }\end{array}$ & Ash & $\begin{array}{l}\text { Crude } \\
\text { fiber }\end{array}$ & $\begin{array}{c}\text { Total } \\
\text { carbohydrates }\end{array}$ & Calories \\
\hline \multicolumn{8}{|l|}{ Rice - based samples } \\
\hline $100 \% \mathrm{RF}$ & $2.63^{\mathrm{cd}}$ & $6.13^{\mathrm{h}}$ & $20.46^{\mathrm{b}}$ & $0.51^{\mathrm{j}}$ & $0.23^{\mathrm{g}}$ & $72.66^{\mathrm{ab}}$ & $499.33^{\mathrm{ab}}$ \\
\hline $50 \% \mathrm{RF}+30 \% \mathrm{SPF}+20 \% \mathrm{SF}$ & $3.46^{\mathrm{b}}$ & $8.56^{\mathrm{e}}$ & $18.47^{\mathrm{d}}$ & $1.10^{\mathrm{gh}}$ & $1.36^{\mathrm{ef}}$ & $70.52^{\mathrm{abcd}}$ & $482.49^{\mathrm{cd}}$ \\
\hline $50 \% \mathrm{RF}+30 \% \mathrm{TF}+20 \% \mathrm{SF}$ & $3.7^{\mathrm{ab}}$ & $9.27^{\mathrm{bcd}}$ & $18.55^{\mathrm{d}}$ & $1.51^{\mathrm{ef}}$ & $1.66^{\text {cde }}$ & $69.00^{\mathrm{abcd}}$ & $480.06^{\mathrm{d}}$ \\
\hline $50 \% \mathrm{RF}+30 \% \mathrm{PF}+20 \% \mathrm{SF}$ & $3.66^{\mathrm{ab}}$ & $8.48^{\mathrm{e}}$ & $18.50^{\mathrm{d}}$ & $1.34^{\mathrm{fg}}$ & $1.38^{\mathrm{ef}}$ & $70.30^{\mathrm{abcd}}$ & $481.65^{\mathrm{cd}}$ \\
\hline \multicolumn{8}{|l|}{ Quinoa - based samples } \\
\hline $100 \% \mathrm{QF}$ & $2.3^{\mathrm{d}}$ & $10.67^{\mathrm{a}}$ & $22.61^{\mathrm{a}}$ & $0.69^{\mathrm{ij}}$ & $1.53^{\mathrm{de}}$ & $64.50^{\mathrm{d}}$ & $504.16^{\mathrm{a}}$ \\
\hline $50 \% \mathrm{QF}+30 \% \mathrm{SPF}+20 \% \mathrm{SF}$ & $3.96^{\mathrm{a}}$ & $9.64^{\mathrm{b}}$ & $18.58^{\mathrm{d}}$ & $1.53^{\mathrm{def}}$ & $1.88^{\text {bcde }}$ & $68.37^{\mathrm{abcd}}$ & $479.28^{\mathrm{d}}$ \\
\hline $50 \% \mathrm{QF}+30 \% \mathrm{TF}+20 \% \mathrm{SF}$ & $4.03^{\mathrm{a}}$ & $10.37^{\mathrm{a}}$ & $20.45^{\mathrm{b}}$ & $1.96^{\mathrm{bc}}$ & $2.19^{\mathrm{abcd}}$ & $65.03^{\mathrm{d}}$ & $485.68^{\mathrm{bcd}}$ \\
\hline $50 \% \mathrm{QF}+30 \% \mathrm{PF}+20 \% \mathrm{SF}$ & $3.43^{\mathrm{b}}$ & $9.53^{\mathrm{bc}}$ & $20.45^{\mathrm{b}}$ & $1.74^{\text {bcde }}$ & $1.88^{\text {bcde }}$ & $66.39^{\mathrm{bcd}}$ & $487.77^{\mathrm{bcd}}$ \\
\hline \multicolumn{8}{|l|}{ Amaranth - based samples } \\
\hline $100 \% \mathrm{AF}$ & $3.43^{\mathrm{b}}$ & $7.57^{\mathrm{f}}$ & $22.22^{\mathrm{a}}$ & $1.43^{\mathrm{ef}}$ & $1.92^{\text {bcde }}$ & $66.86^{\mathrm{bcd}}$ & $497.73^{\mathrm{abc}}$ \\
\hline $50 \% \mathrm{AF}+30 \% \mathrm{SPF}+20 \% \mathrm{SF}$ & $3.43^{\mathrm{b}}$ & $9.31^{\mathrm{bcd}}$ & $20.04^{\mathrm{bc}}$ & $1.83^{\mathrm{bcd}}$ & $2.32^{\mathrm{abc}}$ & $66.49^{\mathrm{bcd}}$ & $483.60^{\text {bcd }}$ \\
\hline $50 \% \mathrm{AF}+30 \% \mathrm{TF}+20 \% \mathrm{SF}$ & $3.76^{\mathrm{ab}}$ & $8.96^{\text {cde }}$ & $20.10^{\mathrm{bc}}$ & $2.35^{\mathrm{a}}$ & $2.64^{\mathrm{a}}$ & $65.95^{\mathrm{cd}}$ & $480.54^{\mathrm{d}}$ \\
\hline $50 \% \mathrm{AF}+30 \% \mathrm{PF}+20 \% \mathrm{SF}$ & $4.1^{\mathrm{a}}$ & $8.93^{\text {cde }}$ & $20.00^{\mathrm{bc}}$ & $2.04^{\mathrm{ab}}$ & $2.37^{\mathrm{ab}}$ & $66.66^{\mathrm{bc}}$ & $482.39^{\mathrm{cd}}$ \\
\hline \multicolumn{8}{|l|}{ Composite flour - based samples } \\
\hline $50 \% \mathrm{RF}+50 \% \mathrm{QF}$ & $4.23^{\mathrm{a}}$ & $7.49^{f}$ & $18.68^{\mathrm{d}}$ & $0.72^{\mathrm{ij}}$ & $0.82^{\mathrm{fg}}$ & $72.29^{\mathrm{abc}}$ & $487.24^{\mathrm{bcd}}$ \\
\hline $50 \% \mathrm{RF}+50 \% \mathrm{AF}$ & $4.13^{\mathrm{a}}$ & $5.72^{\mathrm{h}}$ & $18.40^{\mathrm{d}}$ & $1.00^{\mathrm{hi}}$ & $1.28^{\mathrm{ef}}$ & $73.60^{\mathrm{a}}$ & $482.88^{\mathrm{cd}}$ \\
\hline $50 \% \mathrm{QF}+50 \% \mathrm{AF}$ & $4.03^{\mathrm{a}}$ & $6.81^{\mathrm{g}}$ & $20.29^{\mathrm{b}}$ & $1.44^{\mathrm{ef}}$ & $1.79^{\text {bcde }}$ & $69.68^{\mathrm{abcd}}$ & $488.53^{\mathrm{abcd}}$ \\
\hline $40 \% \mathrm{RF}+30 \% \mathrm{QF}+30 \% \mathrm{AF}$ & $2.9^{c}$ & $5.89^{\mathrm{h}}$ & $19.50^{c}$ & $0.78^{\mathrm{ij}}$ & $2.10^{\mathrm{abcd}}$ & $71.76^{\mathrm{abc}}$ & $486.11^{\text {bcd }}$ \\
\hline $\begin{array}{l}20 \% \mathrm{RF}+15 \% \mathrm{QF}+15 \% \mathrm{AF}+ \\
30 \% \mathrm{SPF}+20 \% \mathrm{SF}\end{array}$ & $4.06^{\mathrm{a}}$ & $8.78^{\mathrm{de}}$ & $19.49^{c}$ & $1.44^{\mathrm{ef}}$ & $1.82^{\text {bcde }}$ & $68.47^{\mathrm{abcd}}$ & $484.42^{\mathrm{bcd}}$ \\
\hline $\begin{array}{l}20 \% \mathrm{RF}+15 \% \mathrm{QF}+15 \% \mathrm{AF}+ \\
30 \% \mathrm{TF}+20 \% \mathrm{SF}\end{array}$ & $3.86^{\mathrm{ab}}$ & $9.53^{\mathrm{bc}}$ & $19.55^{\mathrm{c}}$ & $1.86^{\mathrm{bc}}$ & $2.17^{\mathrm{abcd}}$ & $66.89^{\mathrm{bcd}}$ & $481.60^{\mathrm{d}}$ \\
\hline $\begin{array}{l}20 \% \mathrm{RF}+15 \% \mathrm{QF}+15 \% \mathrm{AF}+ \\
30 \% \mathrm{PF}+20 \% \mathrm{SF}\end{array}$ & $4.26^{\mathrm{a}}$ & $8.67^{\mathrm{de}}$ & $19.53^{\mathrm{c}}$ & $1.67^{\mathrm{cde}}$ & $1.82^{\text {bcde }}$ & $68.31^{\mathrm{abcd}}$ & $483.71^{\mathrm{cd}}$ \\
\hline
\end{tabular}

Each value is mean of three replicates

Means within a column marked with different letters are significantly different at $(p \leq 0.05)$

Rice flour (RF), Quinoa flour (QF), Amaranth flour (AF), Soybean flour (SF), Sweet potato flour (SPF), Taro flour (TF) and Potato flour (PF), Total carbohydrates calculated by difference

Crude fiber is known to aid the digestive system of humans. It has been reported that PF and SPF are good source of fiber (Tiwari et al., 2011; Adeola and Ohizua, 2018) and this could justify the result obtained for the crude fiber and total dietary fiber contents of the biscuits. The quantities of crude fiber varied (increased/ decreased) with other biscuits as substitutes inclusion. All composite flour blends are good source of dietary fiber (Table 3). Food products high in dietary fiber are known as low glycemic index foods and have been shown to reduce postprandial blood glucose and insulin concentration in subjects with diabetes mellitus (Trinidad et al., 2010). Similar observations were made by Chinma et al. (2011) and Okudu and Ojinnaka (2018). 
The carbohydrate contents decreased in the biscuits made from QF or AF, but increased in samples prepared from RF and tuber flours. This observation may be due to the low amount of carbohydrate in QF or $\mathrm{AF}$ and high starch content in tuber flours. Carbohydrates composition in biscuits samples ranged from 73.60 to $65.03 \%$, this ranges were fall within values $(58.2-70.26 \%)$ reported by Omoba and Omojbemile (2013), 67.06-72.42\% (Ikujenlola and Adurotoya, 2014) and 62.96-71.61\% (Okudu and Ojinnaka, 2018).

Energy is a function of the protein, fat and carbohydrate composition of any food product; this could be reason for variation in the energy values of the products. Knowledge of energy values of foods is important in nutrition as that will help individuals with physiological condition to make good food choices (Okudu and Ojinnaka, 2018). Energy (kcal/100g) ranged from 480.06 (50\% RF: $30 \% \mathrm{TF}: 20 \% \mathrm{SF}$ ) to $504.16(100 \%$ QF). Energy was however significantly higher in biscuits produced from quinoa flour than those from other cereals (rice and amaranth).

\section{Physical characteristics of gluten-free biscuits:}

The physical characteristics of resultant biscuit samples are shown in Table (4).

For rice biscuits and its blends, diameter of rice biscuits decreased from 36.53 (100\% RF) to $34.32 \mathrm{~mm}$ (50\% RF: 30\% PF: 20\% SP). Thickness of rice biscuits increased from 6.99 (100\% RF) to $7.15 \mathrm{~mm}$ (50\% RF: $30 \%$ TF: $20 \%$ SP). The spread ratio decreased from 5.24 (100\% RF) to 4.82 (50\% RF: $30 \%$ TF: $20 \%$ SP). For hardness $(\mathrm{N})$ rice $(100 \% \mathrm{RF})$ biscuits had a 1.34 (brittle or crispy) while reach to $4.63 \mathrm{~N}$ in $50 \% \mathrm{RF}$ : $30 \% \mathrm{TF}$ : $20 \%$ SP biscuits.

For quinoa biscuits and its blends, diameter of biscuits decreased from $34.84(100 \%$ QF) to $33.93 \mathrm{~mm}$ (50\% QF: 30\% TF: 20\% SP). Thickness value increased from $6.19(100 \% \mathrm{QF})$ to $6.71 \mathrm{~mm}(50 \mathrm{QF}$ : $30 \% \mathrm{SPF}$ : $20 \% \mathrm{SF})$. The spread ratio decreased from 5.64 (100\% QF) to 5.14 (50 QF: 30\% SPF: 20\% SF). Hardness values increased from 3.92-3.94 (100\% QF, $50 \mathrm{QF}$ : $30 \% \mathrm{SPF}$ : $20 \% \mathrm{PF}$ ) to $5.23 \mathrm{~N}$ (50 QF: $30 \% \mathrm{TF}: 20 \% \mathrm{SF}$ ).

Regarding amaranth biscuits and its blends, diameter values decreased from 36.13 (100\% AF) to $34.18 \mathrm{~mm}$ (50\% AF: $30 \%$ TF: 20\% SF), while thickness decreased from 7.02 (100\% AF) to $6.51 \mathrm{~mm}(50 \% \mathrm{AF}$ : $30 \%$ SPF: $20 \%$ SF). The spread ratio is ranged from $5.14(50 \%$ AF: $30 \%$ PF: $20 \%$ SF) to $5.41(50 \%$ AF: $30 \%$ SPF: $20 \%$ SF). Hardness values were $5.10(50 \%$ AF: $30 \%$ SPF: $20 \% \mathrm{SF})$ to $5.30(100 \% \mathrm{AF}, 50 \% \mathrm{AF}$ : $30 \%$ TF or PF: $20 \%$ SF).

In composite flour biscuits, diameter values ranged from 34.45 (20\% RF: 15\% QF: 15\% AF: $30 \%$ TF: $20 \% \mathrm{SF})$ to $36.28 \mathrm{~mm}(50 \% \mathrm{RF}: 50 \% \mathrm{AF})$, while thickness values were 6.01 (20\% RF: $15 \%$ QF: $15 \%$ AF: $30 \%$ SPF: $20 \%$ SF) to 6.75 (50\% RF: $50 \%$ AF). The spread ratio ranged from 5.38 (50\% RF: $50 \% \mathrm{AF})$ to $5.82(50 \%$ RF: $50 \%$ QF). Hardness values ranged from $2.20(50 \% \mathrm{RF}: 50 \% \mathrm{QF})$ (brittle or fragility) to 5.08 (20\% RF: 15\% QF: 15\% AF: 30\% TF: 20\% SF) (dense and hard).
From Table (4), the hardness values of RF biscuits samples were lower than the other samples. According to Esteller and Lannes (2005), hardness evaluated for baking products depends on many factors, such as the flour quality, moisture of the dough, emulsifiers and enzymes, among others. Moreover, baking conditions, the type, quantity of ingredients, and protein content of the flour used have been reported to inference its hardness (Adeola and Ohizua, 2018). The result suggested that blends having high tubers flours would be suitable to maintain its shape during transportation. Similar results for hardness of biscuit with increased incorporation of tubers flours were reported by Sharoba et al. (2014).

Doporto et al. (2017) and McWatters et al. (2003) reported that the hardness of cookies and biscuits is caused by the interaction of protein and starch by hydrogen bonding during dough development and baking. On the other hand, the texture of gluten-free biscuits is primarily attributable to starch gelatinization and super-cooled sugar rather than to protein-starch structure development (de-Simas et al., 2009).

Also, Doporto et al. (2017) reported that the fracture force rose with increasing flour protein content. On the other hand, de Simas et al. (2009) found a similar trend working on gluten-free cookies containing king palm flour as rich-fiber ingredient. Influence of amaranth flour at different levels on the texture of gluten-free biscuits which had the highest hardness value. The same trend, noticed with sweet potato or taro or potato flours addition (Table 4). The addition of amaranth and quinoa with rice at ratio $(30 \% \mathrm{AF}: 30 \% \mathrm{QF}: 40 \% \mathrm{RF})$ rose the hardness value (Table 4). The use of rice flour (100\%) gave brittle crispers texture (less hardness) which preferable at the panelists (Tables 4 and 6).

The spread ratio was decreased (4.82) when composite flours (rice: taro: soybean, 50:30: 20) used. The results are in agreement with Sharoba et al. (2014). Akubor and Ukwuru (2003) reported that spread ratio of cookies made with high protein flour does not develop during baking, as non-wheat high protein flours used in biscuit exhibited greater water retention. The spread ratio is mainly influenced by the dough expansion, its flow during baking and set time (Sozer et al., 2014). Biscuit flours are generally weak and flow faster as compared to bread flours (Sozer et al., 2014). The available water is free to act as a solvent will strengthen the dough without significant protein network formation and will turn the structure into a thermoplastic mass (Kweon et al., 2009).

\section{Color attributes of gluten-free biscuit:}

Color is an important because it can arouse individual's appetite. It is one of the parameters used for process control during baking and roasting, because brown pigments appear as browning and caramelization reactions progress (Pereira et al., 2013).

For rice biscuits and its blends, $L^{*}$ values decreased from 59.85 (100\% RF) to 42.05 (50\% RF: $30 \%$ TF: $20 \%$ SF). $L^{*}$ values were decreased significantly between $100 \% \mathrm{RF}$ biscuit and the rest biscuits samples (Table 5). The $a^{*}$ values of the biscuit 
samples increased from $10.75(100 \% \mathrm{RF})$ to $13.83(50 \%$ RF: $30 \%$ SPF: $20 \% \mathrm{SF})$. The $b^{*}$ values ranged from 27.05 (50\% RF: $30 \%$ TF: $20 \%$ SF) to 37.50 (50\% RF: $30 \%$ SPF: $20 \%$ SF). Chroma values $\left(C^{*}\right)$ decreased from 34.03 (100\% RF) to 29.88 (50\% RF: $30 \%$ TF: $20 \% \mathrm{SF}$ ). The same trend, Whiteness index (WI) were 47.28 (100\% RF) to 30.86 (50\% RF: $30 \%$ SPF: $20 \%$ $\mathrm{SF})$. The browning index (BI) increased from 87.87 (100\% RF) to 176.31 (50\% RF: 30\% SPF: $20 \%$ SF).

For quinoa biscuits and its blends, $L^{*}$ values of the samples decreased significantly $(\mathrm{P} \leq 0.05)$ from 44.55 (100\% QF) to 33.25 (50\% QF: $30 \%$ SPF: $20 \%$ SF). The $a^{*}$ values of the biscuit samples ranged from 12.50 (50\% QF: 30\% SPF: 20\% SF) to 15.80 (50\% QF: $30 \%$ PF: $20 \% \mathrm{SF})$. The $b^{*}$ values decreased significantly $(\mathrm{P} \leq 0.05)$ from $31.40(100 \% \mathrm{QF})$ to $26.55(50 \% \mathrm{QF}$ : $30 \%$ SPF: $20 \%$ SF). Chroma values $\left(C^{*}\right)$ ranged from $29.43(50 \%$ QF: $30 \%$ SPF: $20 \%$ SF) to $35.02(50 \%$ QF: 30\% PF: $20 \%$ SF). Whiteness index (WI) decreased significantly $(\mathrm{P} \leq 0.05)$ from $34.75(100 \% \mathrm{QF})$ to 27.00
(50\% QF: 30\% SPF: 20\% SF). Browning index (BI) increased from 133.45 (100\% QF) to 165.06 (50\% QF: $30 \%$ SPF: $20 \%$ SF).

In the case of amaranth biscuits and its blends, $L^{*}$ values of the samples decreased significantly $(\mathrm{P} \leq 0.05)$ from $44.73(100 \% \mathrm{AF})$ to 36.83 (50\% AF: $30 \%$ PF: $20 \% \mathrm{SF})$. The $a^{*}$ values of the biscuit samples ranged from $11.63(50 \%$ AF: $30 \%$ TF: $20 \% \mathrm{SF})$ to $12.33(50 \%$ AF: $30 \%$ SPF: $20 \%$ SF) and $b *$ values were from 25.50 (50\% AF: $30 \%$ PF: $20 \%$ SF) to 31.65 (50\% AF: $30 \%$ SPF: $20 \% \mathrm{SF})$. Chroma values $\left(C^{*}\right)$ ranged from 28.18 (50\% AF: $30 \%$ TF: $20 \%$ SF) to 33.97 (50\% AF: $30 \%$ SPF: $20 \% \mathrm{SF}) . C^{*}$ values were significantly difference between samples. Whiteness index (WI) decreased significantly $(\mathrm{P} \leq 0.05)$ from $37.71(100 \% \mathrm{AF})$ to 29.59 (50\% AF: $30 \%$ SPF: $20 \%$ SF). Browning index (BI) increased from $102.67(100 \% \mathrm{AF})$ to 172.40 (50\% AF: $30 \%$ SPF: $20 \%$ SF). BI values were increased significantly $(\mathrm{P} \leq 0.05)$ between the tested samples.

Table (4): Diameter, thickness, spread ratio and hardness of gluten free biscuits produced from rice, quinoa and amaranth flours with some tuber flours

\begin{tabular}{|c|c|c|c|c|}
\hline Biscuit samples & $\begin{array}{c}\text { Diameter } \\
(\mathbf{m m})\end{array}$ & Thickness (mm) & Spread ratio & Hardness (N) \\
\hline \multicolumn{5}{|l|}{ Rice - based samples } \\
\hline $100 \% \mathrm{RF}$ & $36.53^{\mathrm{a}}$ & $6.99^{\mathrm{abc}}$ & $5.24^{\text {cde }}$ & $1.34^{\mathrm{g}}$ \\
\hline $50 \% \mathrm{RF}+30 \% \mathrm{SPF}+20 \% \mathrm{SF}$ & $34.92^{\text {cdef }}$ & $6.78^{\mathrm{bcd}}$ & $5.17^{\mathrm{de}}$ & $3.23^{\mathrm{e}}$ \\
\hline $50 \% \mathrm{RF}+30 \% \mathrm{TF}+20 \% \mathrm{SF}$ & $34.35^{\mathrm{efg}}$ & $7.15^{\mathrm{a}}$ & $4.82^{\mathrm{f}}$ & $4.63^{\mathrm{bc}}$ \\
\hline $50 \% \mathrm{RF}+30 \% \mathrm{PF}+20 \% \mathrm{SF}$ & $34.32^{\text {efg }}$ & $6.68^{\mathrm{bcd}}$ & $5.15^{\mathrm{de}}$ & $3.21^{\mathrm{e}}$ \\
\hline \multicolumn{5}{|l|}{ Quinoa - based samples } \\
\hline $100 \% \mathrm{QF}$ & $34.84^{\text {cdefg }}$ & $6.19^{\mathrm{fgh}}$ & $5.64^{\mathrm{ab}}$ & $3.94^{\mathrm{d}}$ \\
\hline $50 \% \mathrm{QF}+30 \% \mathrm{SPF}+20 \% \mathrm{SF}$ & $34.46^{\text {defg }}$ & $6.71^{\mathrm{bcd}}$ & $5.14^{\mathrm{e}}$ & $3.92^{\mathrm{d}}$ \\
\hline $50 \% \mathrm{QF}+30 \% \mathrm{TF}+20 \% \mathrm{SF}$ & $33.93^{\mathrm{g}}$ & $6.46^{\mathrm{def}}$ & $5.25^{\mathrm{cde}}$ & $5.23^{\mathrm{a}}$ \\
\hline $50 \% \mathrm{QF}+30 \% \mathrm{PF}+20 \% \mathrm{SF}$ & $34.08^{\mathrm{fg}}$ & $6.50^{\mathrm{def}}$ & $5.25^{\mathrm{cde}}$ & $5.07^{\mathrm{ab}}$ \\
\hline \multicolumn{5}{|l|}{ Amaranth - based samples } \\
\hline $100 \% \mathrm{AF}$ & $36.13^{\mathrm{ab}}$ & $7.02^{\mathrm{ab}}$ & $5.15^{\mathrm{de}}$ & $5.30^{\mathrm{a}}$ \\
\hline $50 \% \mathrm{AF}+30 \% \mathrm{SPF}+20 \% \mathrm{SF}$ & $35.11^{\mathrm{cde}}$ & $6.51^{\mathrm{def}}$ & $5.41^{\text {bcde }}$ & $5.10^{\mathrm{ab}}$ \\
\hline $50 \% \mathrm{AF}+30 \% \mathrm{TF}+20 \% \mathrm{SF}$ & $34.18^{\mathrm{fg}}$ & $6.65^{\mathrm{cde}}$ & $5.16^{\mathrm{de}}$ & $5.30^{\mathrm{a}}$ \\
\hline $50 \% \mathrm{AF}+30 \% \mathrm{PF}+20 \% \mathrm{SF}$ & $34.46^{\text {defg }}$ & $6.73^{\text {bcd }}$ & $5.14^{\mathrm{e}}$ & $5.30^{\mathrm{a}}$ \\
\hline \multicolumn{5}{|l|}{ Composite flour - based samples } \\
\hline $50 \% \mathrm{RF}+50 \% \mathrm{QF}$ & $35.35^{\text {bcd }}$ & $6.09^{\mathrm{gh}}$ & $5.82^{\mathrm{a}}$ & $2.20^{\mathrm{f}}$ \\
\hline $50 \% \mathrm{RF}+50 \% \mathrm{AF}$ & $36.28^{\mathrm{a}}$ & $6.75^{\mathrm{bcd}}$ & $5.38^{\text {bcde }}$ & $4.58^{\mathrm{bc}}$ \\
\hline $50 \% \mathrm{QF}+50 \% \mathrm{AF}$ & $35.40^{\mathrm{bc}}$ & $6.42^{\mathrm{defg}}$ & $5.52^{\mathrm{bc}}$ & $5.04^{\mathrm{ab}}$ \\
\hline $40 \% \mathrm{RF}+30 \% \mathrm{QF}+30 \% \mathrm{AF}$ & $35.36^{\text {bcd }}$ & $6.51^{\mathrm{def}}$ & $5.44^{\mathrm{bcd}}$ & $5.30^{\mathrm{a}}$ \\
\hline $\begin{array}{l}20 \% \mathrm{RF}+15 \% \mathrm{QF}+15 \% \mathrm{AF}+30 \% \\
\mathrm{SPF}+20 \% \mathrm{SF}\end{array}$ & $34.74^{\text {cdefg }}$ & $6.01^{\mathrm{h}}$ & $5.78^{\mathrm{a}}$ & $4.15^{\mathrm{cd}}$ \\
\hline $\begin{array}{l}20 \% \mathrm{RF}+15 \% \mathrm{QF}+15 \% \mathrm{AF}+30 \% \\
\mathrm{TF}+20 \% \mathrm{SF}\end{array}$ & $34.45^{\text {defg }}$ & $6.29^{\text {efgh }}$ & $5.48^{\mathrm{bc}}$ & $5.08^{\mathrm{ab}}$ \\
\hline $\begin{array}{l}20 \% \mathrm{RF}+15 \% \mathrm{QF}+15 \% \mathrm{AF}+30 \% \mathrm{PF} \\
+20 \% \mathrm{SF}\end{array}$ & $34.63^{\text {cdefg }}$ & $6.25^{\text {fgh }}$ & $5.56^{\mathrm{ab}}$ & $4.83^{\mathrm{ab}}$ \\
\hline
\end{tabular}

Each value is mean of tin replicates

Means within a column marked with different letters are significantly different at $(p \leq 0.05)$

Rice flour (RF), Quinoa flour (QF), Amaranth flour (AF), Soybean flour (SF), Sweet potato flour (SPF), Taro flour (TF) and Potato flour (PF)

$\mathrm{N}=$ Newton units 
Regarding the composite flour biscuits, $L^{*}$ values of the biscuit samples ranged from 20.13 (20\% RF: $15 \%$ QF: $15 \%$ AF: 30\% SPF: 20\% SF) to 57.97 (50\% RF: $50 \% \quad \mathrm{AF}) . L^{*}$ values were significantly $(\mathrm{P} \leqq 0.05)$ different between the samples. The $a^{*}$ values of the biscuit samples ranged from 7.07 (50\% RF: 50\% AF) to 12.43 (20\% RF: 15\% QF: 15\% AF: $30 \%$ PF: $20 \%$ SF); this values were significantly $(\mathrm{P} \leq 0.05)$ different. The $b^{*}$ values were from 19.13 (20\% RF: 15\% QF: $15 \%$ AF: $30 \%$ SPF: $20 \%$ SF) to 29.28 (20\% RF: $15 \%$ QF: $15 \%$ AF: $30 \%$ PF: $20 \%$ SF); this values were significantly
$(\mathrm{P} \leqq 0.05)$ different between the samples. Chroma values $\left(C^{*}\right)$ ranged from 21.19 (20\% RF: 15\% QF: 15\% AF: $30 \%$ SPF: $20 \%$ SF) to 31.81 (20\% RF: $15 \%$ QF: $15 \%$ AF: $30 \%$ PF: $20 \%$ SF). Whiteness index (WI) ranged from 17.17 (20\% RF: 15\% QF: 15\% AF: 30\% SPF: $20 \% \mathrm{SF}$ ) to 49.38 (50\% RF: $50 \% \mathrm{AF})$. Browning index (BI) ranged from 70.22 (50\% RF: $50 \% \mathrm{AF})$ to 238.40 (20\% RF: $15 \%$ QF: $15 \%$ AF: $30 \%$ SPF: $20 \%$ SF). WI and $\mathrm{BI}$ values were significantly $(\mathrm{P} \leqq 0.05)$ different between samples.

Table (5): Color attributes of gluten free biscuits produced from rice, quinoa and amaranth flours with some tuber flours

\begin{tabular}{|c|c|c|c|c|c|c|}
\hline Biscuit samples & $L^{*}$ & $a^{*}$ & $b^{*}$ & $C^{*}$ & WI & BI \\
\hline \multicolumn{7}{|l|}{ Rice - based samples } \\
\hline $100 \% \mathrm{RF}$ & $59.85^{\mathrm{a}}$ & $10.75^{\text {cdef }}$ & $32.25^{\mathrm{b}}$ & $34.03^{\mathrm{bc}}$ & $47.28^{\mathrm{a}}$ & $87.87^{\mathrm{de}}$ \\
\hline $50 \% \mathrm{RF}+30 \% \mathrm{SPF}+20 \% \mathrm{SF}$ & $43.60^{\mathrm{bcd}}$ & $13.83^{\mathrm{ab}}$ & $37.50^{\mathrm{a}}$ & $39.97^{\mathrm{a}}$ & $30.86^{\mathrm{cde}}$ & $176.31^{\mathrm{abc}}$ \\
\hline $50 \% \mathrm{RF}+30 \% \mathrm{TF}+20 \% \mathrm{SF}$ & $42.05^{\text {bcde }}$ & $12.65^{\mathrm{bcd}}$ & $27.05^{\mathrm{cd}}$ & $29.88^{\text {cde }}$ & $34.78^{\mathrm{bcd}}$ & $118.50^{\text {cde }}$ \\
\hline $50 \% \mathrm{RF}+30 \% \mathrm{PF}+20 \% \mathrm{SF}$ & $47.05^{\mathrm{b}}$ & $13.03^{\mathrm{bc}}$ & $32.93^{\mathrm{b}}$ & $35.41^{\mathrm{b}}$ & $36.30^{\mathrm{bc}}$ & $128.73^{\text {bcde }}$ \\
\hline \multicolumn{7}{|l|}{ Quinoa - based samples } \\
\hline $100 \% \mathrm{QF}$ & $44.55^{\mathrm{bc}}$ & $13.83^{\mathrm{ab}}$ & $31.40^{\mathrm{bc}}$ & $34.33^{\mathrm{b}}$ & $34.75^{\mathrm{bcd}}$ & $133.45^{\text {bcde }}$ \\
\hline $50 \% \mathrm{QF}+30 \% \mathrm{SPF}+20 \% \mathrm{SF}$ & $33.25^{\mathrm{f}}$ & $12.50^{\mathrm{bcd}}$ & $26.55^{\mathrm{de}}$ & $29.43^{\mathrm{de}}$ & $27.00^{\mathrm{e}}$ & $165.06^{\mathrm{bcd}}$ \\
\hline $50 \% \mathrm{QF}+30 \% \mathrm{TF}+20 \% \mathrm{SF}$ & $38.85^{\text {cdef }}$ & $13.95^{\mathrm{ab}}$ & $28.45^{\mathrm{bcd}}$ & $31.80^{\mathrm{bcd}}$ & $31.06^{\text {cde }}$ & $152.53^{\mathrm{bcd}}$ \\
\hline $50 \% \mathrm{QF}+30 \% \mathrm{PF}+20 \% \mathrm{SF}$ & $42.93^{\mathrm{bcd}}$ & $15.80^{\mathrm{a}}$ & $31.23^{\mathrm{bc}}$ & $35.02^{\mathrm{b}}$ & $33.03^{\text {bcde }}$ & $142.12^{\text {bcde }}$ \\
\hline \multicolumn{7}{|l|}{ Amaranth - based samples } \\
\hline $100 \% \mathrm{AF}$ & $44.73^{\mathrm{bc}}$ & $12.17^{\mathrm{bcd}}$ & $25.95^{\mathrm{de}}$ & $28.71^{\text {def }}$ & $37.71^{\mathrm{b}}$ & $102.67^{\text {cde }}$ \\
\hline $50 \% \mathrm{AF}+30 \% \mathrm{SPF}+20 \% \mathrm{SF}$ & $38.33^{\text {cdef }}$ & $12.33^{\mathrm{bcd}}$ & $31.65^{\mathrm{bc}}$ & $33.97^{\mathrm{bc}}$ & $29.59^{\mathrm{de}}$ & $172.40^{\mathrm{abc}}$ \\
\hline $50 \% \mathrm{AF}+30 \% \mathrm{TF}+20 \% \mathrm{SF}$ & $38.17^{\text {cdef }}$ & $11.63^{\text {bcde }}$ & $25.60^{\text {de }}$ & $28.18^{\mathrm{def}}$ & $32.07^{\text {bcde }}$ & $124.43^{\text {bcde }}$ \\
\hline $50 \% \mathrm{AF}+30 \% \mathrm{PF}+20 \% \mathrm{SF}$ & $36.83^{\text {def }}$ & $12.00^{\mathrm{bcd}}$ & $25.50^{\text {de }}$ & $28.20^{\text {def }}$ & $30.71^{\text {cde }}$ & $134.05^{\text {bcde }}$ \\
\hline \multicolumn{7}{|l|}{ Composite flour - based samples } \\
\hline $50 \% \mathrm{RF}+50 \% \mathrm{QF}$ & $42.75^{\text {bcde }}$ & $10.50^{\text {def }}$ & $29.15^{\text {bcd }}$ & $31.00^{\text {bcde }}$ & $34.70^{\text {bcd }}$ & $125.78^{\text {bcde }}$ \\
\hline $50 \% \mathrm{RF}+50 \% \mathrm{AF}$ & $57.97^{\mathrm{a}}$ & $7.07^{\mathrm{g}}$ & $27.30^{\mathrm{cd}}$ & $28.20^{\mathrm{def}}$ & $49.38^{\mathrm{a}}$ & $70.22^{\mathrm{e}}$ \\
\hline $50 \% \mathrm{QF}+50 \% \mathrm{AF}$ & $38.05^{\text {cdef }}$ & $10.85^{\text {cdef }}$ & $24.73^{\mathrm{de}}$ & $27.07^{\mathrm{ef}}$ & $32.21^{\text {bcde }}$ & $122.47^{\text {cde }}$ \\
\hline $40 \% \mathrm{RF}+30 \% \mathrm{QF}+30 \% \mathrm{AF}$ & $33.45^{\mathrm{f}}$ & $10.51^{\mathrm{def}}$ & $27.58^{\mathrm{cd}}$ & $29.56^{\mathrm{de}}$ & $27.16^{\mathrm{e}}$ & $201.21^{\mathrm{ab}}$ \\
\hline $\begin{array}{l}20 \% \mathrm{RF}+15 \% \mathrm{QF}+15 \% \mathrm{AF}+ \\
30 \% \mathrm{SPF}+20 \% \mathrm{SF}\end{array}$ & $20.13^{\mathrm{g}}$ & $8.85^{\mathrm{fg}}$ & $19.13^{\mathrm{f}}$ & $21.19^{\mathrm{g}}$ & $17.17^{\mathrm{f}}$ & $238.40^{\mathrm{a}}$ \\
\hline $\begin{array}{l}20 \% \mathrm{RF}+15 \% \mathrm{QF}+15 \% \mathrm{AF}+ \\
30 \% \mathrm{TF}+20 \% \mathrm{SF}\end{array}$ & $35.75^{\mathrm{ef}}$ & $9.60^{\mathrm{ef}}$ & $22.40^{\mathrm{ef}}$ & $24.37^{\text {fg }}$ & $31.28^{\text {bcde }}$ & $111.37^{\text {cde }}$ \\
\hline $\begin{array}{l}20 \% \mathrm{RF}+15 \% \mathrm{QF}+15 \% \mathrm{AF}+ \\
30 \% \mathrm{PF}+20 \% \mathrm{SF}\end{array}$ & $39.80^{\text {cdef }}$ & $12.43^{\mathrm{bcd}}$ & $29.28^{\mathrm{bcd}}$ & $31.81^{\mathrm{bcd}}$ & $31.85^{\text {bcde }}$ & $142.27^{\text {bcde }}$ \\
\hline
\end{tabular}

Each value is mean of five replicates

Means within a column marked with different letters are significantly different at $(p \leq 0.05)$

Rice flour (RF), Quinoa flour (QF), Amaranth flour (AF), Soybean flour (SF), Sweet potato flour (SPF), Taro flour (TF) and Potato flour (PF)

From Table (5), the positive values of $a^{*}$ and $b^{*}$ values indicated that the predominance of redness and yellowness in the biscuit samples. The color of the biscuits changed to dark brown from creamy yellow as the inclusion of tuber flours. Whiteness ( $L^{*}$ values) of biscuits was decreased with adding of tuber flours.

According to Bassinello et al. (2011), the instrumental color parameters in this type products vary with the type of flour and processing, especially the baking. Once, the baking conditions were the same for all treatments, the most important source of variation in this study was the composition. The high protein content increased the formation of Maillard reaction products during baking. The current result in similar to findings of other studies (Pereira et al., 2013; Adeola and Ohizua, 2018). The browning of the baked products 
increased with sweet potato flour, for example the BI value of RF biscuits was 87.87 , which significantly lower than the value for 50\% RF: $30 \%$ SPF: $20 \%$ SF $(\mathrm{BI}=176.31)$. This could be attributed to the Maillard reaction browning products between protein and reducing sugar during baking. According to McWatters et al. (2003) and Doporto et al. (2017), cookie surface color is the result of non-enzymatic browning between reducing sugar and amino acids as well as from starch dextrinization and sugar caramelization.

\section{Sensory evaluation of gluten-free biscuits:}

Sensory quality is considered a key factor in food acceptance because consumers look out for food with specific sensory characteristics (Bello et al., 2018). Gluten-free biscuits supplemented by different levels of substitutions of seed and /or tubers flours were sensory evaluated and compared with control biscuits $100 \%$ RF. Sensory characteristics of aglutenics biscuits are presented in Table (6).
For rice biscuits and its blends, scores for taste, color, crispness, appearance and acceptability (8.50, $8.69,8.19,8.75$ and 8.81) for biscuit produced from $100 \%$ RF (control), were significantly higher than scores obtained from all resultant biscuits. RF biscuit (control) were rated to be significantly $(\mathrm{p} \leq 0.05)$ better in terms of taste, color, crispness, appearance and acceptability than the remaining gluten free biscuits.

In quinoa biscuits and its blends, the $100 \% \mathrm{QF}$ had a slightly like score (6.31) for consumer preference, while the rest biscuit samples had low scores in all attributes.

For amaranth biscuits and its blends, all samples gave the scores less 6.00.

In the case of composite flour biscuits, the biscuits produced from composite flours 50\% RF: $50 \%$ QF, $40 \%$ RF: $30 \%$ QF: $30 \%$ AF and 50\% RF: $50 \%$ AF had higher values (7.94, 7.69 and 7.56, respectively). The differences between these samples were nonsignificant.

Table (6): Sensory evaluation scores of gluten free biscuits produced from rice, quinoa and amaranth flours with some tuber flours

\begin{tabular}{|c|c|c|c|c|c|}
\hline Biscuit samples & Taste & Color & Crispness & Appearance & Acceptability \\
\hline \multicolumn{6}{|l|}{ Rice - based samples } \\
\hline $100 \% \mathrm{RF}$ & $8.50^{\mathrm{a}}$ & $8.69^{a}$ & $8.19^{a}$ & $8.75^{\mathrm{a}}$ & $8.81^{\mathrm{a}}$ \\
\hline $50 \% \mathrm{RF}+30 \% \mathrm{SPF}+20 \% \mathrm{SF}$ & $5.50^{\text {cdef }}$ & $5.25^{\text {cde }}$ & $5.50^{\mathrm{cd}}$ & $5.25^{\mathrm{cd}}$ & $5.63^{\mathrm{cd}}$ \\
\hline $50 \% \mathrm{RF}+30 \% \mathrm{TF}+20 \% \mathrm{SF}$ & $5.00^{\mathrm{def}}$ & $4.75^{\mathrm{cde}}$ & $4.75^{\mathrm{d}}$ & $5.13^{\mathrm{cd}}$ & $5.06^{\mathrm{cd}}$ \\
\hline $50 \% \mathrm{RF}+30 \% \mathrm{PF}+20 \% \mathrm{SF}$ & $5.44^{\text {cdef }}$ & $6.19^{\mathrm{bcd}}$ & $5.19^{d}$ & $5.50^{\mathrm{cd}}$ & $5.44^{\mathrm{cd}}$ \\
\hline \multicolumn{6}{|l|}{ Quinoa - based samples } \\
\hline $100 \% \mathrm{QF}$ & $5.88^{\mathrm{cde}}$ & $6.38^{\mathrm{bc}}$ & $6.00^{\mathrm{bcd}}$ & $6.56^{\mathrm{bc}}$ & $6.31^{\mathrm{bc}}$ \\
\hline $50 \% \mathrm{QF}+30 \% \mathrm{SPF}+20 \% \mathrm{SF}$ & $5.56^{\mathrm{cdef}}$ & $5.00^{\text {cde }}$ & $4.56^{\mathrm{d}}$ & $5.00^{\mathrm{cd}}$ & $4.94^{\mathrm{cd}}$ \\
\hline $50 \% \mathrm{QF}+30 \% \mathrm{TF}+20 \% \mathrm{SF}$ & $5.38^{\text {cdef }}$ & $4.50^{\mathrm{de}}$ & $4.31^{\mathrm{d}}$ & $4.44^{\mathrm{d}}$ & $4.38^{\mathrm{d}}$ \\
\hline $50 \% \mathrm{QF}+30 \% \mathrm{PF}+20 \% \mathrm{SF}$ & $5.06^{\text {cdef }}$ & $5.44^{\text {cde }}$ & $4.88^{\mathrm{d}}$ & $4.88^{\mathrm{cd}}$ & $5.06^{\mathrm{cd}}$ \\
\hline \multicolumn{6}{|l|}{ Amaranth - based samples } \\
\hline $100 \% \mathrm{AF}$ & $4.75^{\mathrm{def}}$ & $5.38^{\text {cde }}$ & $4.94^{\mathrm{d}}$ & $5.13^{\mathrm{cd}}$ & $5.13^{\mathrm{cd}}$ \\
\hline $50 \% \mathrm{AF}+30 \% \mathrm{SPF}+20 \% \mathrm{SF}$ & $4.31^{\mathrm{ef}}$ & $4.38^{\mathrm{e}}$ & $4.13^{\mathrm{d}}$ & $4.19^{\mathrm{d}}$ & $4.19^{\mathrm{d}}$ \\
\hline $50 \% \mathrm{AF}+30 \% \mathrm{TF}+20 \% \mathrm{SF}$ & $4.00^{f}$ & $4.19^{\mathrm{e}}$ & $4.13^{\mathrm{d}}$ & $4.31^{\mathrm{d}}$ & $4.13^{\mathrm{d}}$ \\
\hline $50 \% \mathrm{AF}+30 \% \mathrm{PF}+20 \% \mathrm{SF}$ & $4.69^{\mathrm{def}}$ & $4.81^{\text {cde }}$ & $4.38^{\mathrm{d}}$ & $5.00^{\mathrm{cd}}$ & $4.63^{\mathrm{cd}}$ \\
\hline \multicolumn{6}{|l|}{ Composite flour - based samples } \\
\hline $50 \% \mathrm{RF}+50 \% \mathrm{QF}$ & $7.69^{\mathrm{ab}}$ & $8.19^{\mathrm{a}}$ & $7.75^{\mathrm{ab}}$ & $7.88^{\mathrm{ab}}$ & $7.94^{\mathrm{ab}}$ \\
\hline $50 \% \mathrm{RF}+50 \% \mathrm{AF}$ & $7.75^{\mathrm{ab}}$ & $7.88^{\mathrm{a}}$ & $7.31^{\mathrm{abc}}$ & $7.50^{\mathrm{ab}}$ & $7.56^{\mathrm{ab}}$ \\
\hline $50 \% \mathrm{QF}+50 \% \mathrm{AF}$ & $6.56^{\mathrm{bcd}}$ & $5.56^{\mathrm{cde}}$ & $5.00^{\mathrm{d}}$ & $5.63^{\mathrm{cd}}$ & $5.75^{\mathrm{cd}}$ \\
\hline $40 \% \mathrm{RF}+30 \% \mathrm{QF}+30 \% \mathrm{AF}$ & $6.88^{\mathrm{abc}}$ & $7.44^{\mathrm{ab}}$ & $7.19^{\mathrm{abc}}$ & $7.31^{\mathrm{ab}}$ & $7.69^{\mathrm{ab}}$ \\
\hline $\begin{array}{l}20 \% \mathrm{RF}+15 \% \mathrm{QF}+15 \% \mathrm{AF}+ \\
30 \% \mathrm{SPF}+20 \% \mathrm{SF}\end{array}$ & $5.06^{\text {cdef }}$ & $4.88^{\text {cde }}$ & $4.69^{d}$ & $5.06^{\mathrm{cd}}$ & $5.06^{\mathrm{cd}}$ \\
\hline $\begin{array}{l}20 \% \mathrm{RF}+15 \% \mathrm{QF}+15 \% \mathrm{AF}+ \\
30 \% \mathrm{TF}+20 \% \mathrm{SF}\end{array}$ & $5.06^{\text {cdef }}$ & $4.69^{\text {cde }}$ & $4.94^{\mathrm{d}}$ & $4.63^{\mathrm{d}}$ & $5.00^{\mathrm{cd}}$ \\
\hline $\begin{array}{l}20 \% \mathrm{RF}+15 \% \mathrm{QF}+15 \% \mathrm{AF}+ \\
30 \% \mathrm{PF}+20 \% \mathrm{SF}\end{array}$ & $5.63^{\text {cdef }}$ & $5.69^{\text {cde }}$ & $5.50^{\mathrm{cd}}$ & $5.31^{\mathrm{cd}}$ & $5.38^{\mathrm{cd}}$ \\
\hline
\end{tabular}

Means within a column marked with different letters are significantly different at $(p \leq 0.05)$

Rice flour (RF), Quinoa flour (QF), Amaranth flour (AF), Soybean flour (SF), Sweet potato flour (SPF), Taro flour (TF) and Potato flour (PF) 
Data indicated that thescore of biscuits containing $100 \%$ rice flour (control) were found to be the most acceptable (8.81- like very much). At $100 \%$ level of rice flour biscuit, all the attributes scored the highest level. The taste, color, crispness and appearance scores of rice biscuits reached maximum than to the rest of the samples. $100 \%$ rice biscuit > rice: quinoa biscuit $(50: 50)>$ rice: quinoa: amaranth biscuit $(40: 30: 30)>$ rice: amaranth biscuit (50:50).

The taste of biscuits produced from 100\% RF (8.50), composite flour (50\% RF: $50 \%$ AF) (7.75) and composite (50\% RF: $50 \%$ QF) flour (7.69) was comparable with that of all rest samples $(7.00-6.88)$, this types was slightly in terms of color while biscuit from the composite flour was moderately liked. The score of color reduced significantly to 4.19 , this was due to increasing the level of tubers (taro, sweet potato and potato) flours which gave a dark brown color to biscuit which was not liked much by the panelist. Similarly, the score of taste, crispness and appearance also reduced significantly. This was because of typical flavor component and caramelization of free sugar in sweet potato flour during baking (Singh, 2008).

It is evident from the study thatbiscuits produced from whole rice flour and substitution of quinoa or amaranth flour of 50:50 and composite flours (rice: quinoa: amaranth, 40:30:30) was most acceptable in the taste, color, crispness, appearance and consumer preference (acceptability). The observed trend for appearance, crispness and color may be attributed to the fact that gluten free biscuit from these blends appeared brighter and crispness (brittle) compared to gluten-free biscuits made from the other flours. Acceptability (consumer preference) scores for gluten-free biscuits from whole flours: rice (8.81) like very much, quinoa (6.31) fair, and amaranth (5.13) dislike.

The results indicated that panelists were generally in-different to the taste of biscuits from cereals and tubers flours. These biscuit samples received a mean score of 4.00 (dislike slightly) and 5.88 ("neither like nor dislike"), respectively. Panelists were more inclined towards the taste of biscuits made from rice flour, and this obtained a mean score of 8.50 ("like very much").

\section{CONCLUSION}

Gluten-free flours combinations could be used to produce good quality biscuits with acceptable nutritional, physical and sensory qualities. These biscuits are advantageous for people suffering from gluten intolerance and low income groups. The glutenfree biscuits had good protein content. Gluten free biscuits made from rice flour, rice: quinoa, rice: quinoa: amaranth and rice: amaranth flours were quite promising, showing higher acceptability rating compared to biscuits of acceptable nutritional and sensorial properties could be produced from composite flours made from rice and quinoa or amaranth or its blends.

\section{REFERENCES}

AACC (2002). Approved Method of American Association of Cereal Chemists. Approved Methods the A.A.C.C. published by the American Association of Cereal Chemists. 13 ${ }^{\text {th }}$ Ed., Inc. St. Paul, Minnesota, USA.

Abd El-Hady, E.A. (2002). Amaranth meal as a protein and essential amino acids supplement in some extrudates, cookies and macaroni. Arab Univ. J. Agric. Sci., Ain Shams Univ., Cairo, 10(12): 707.

Adeola, A.A. and E. R. Ohizua (2018). Physical, chemical, and sensory properties of biscuits prepared from flour blends of unripe cooking banana, pigeon pea, and sweet potato. Food Sci. Nutr., 6: 532-540.

Ahmed, M., S. Hussein, A. Nefisa, K. Hegazy, A. Thanaa and A. Ibrahim (2012). Production and evaluation of gluten-free cakes. Australian J. Basic and Applied Sci., 6(12): 482-491.

Akonor, P. T., C. Tortoe, E. S. Buckman and L. Hagan (2017). Proximate composition and sensory evaluation of root and tuber composite flour noodles. Cogent Food \& Agriculture, 3: 1-7.

Akubor, B. I. and M. Ukwuru (2003). Functional properties and biscuit making potential of soybean and cassava flour blends. Plant Foods for Human Nutr., 58: 1-12.

Aly, M. M. A. and H. A. Seleem (2015). Gluten-free flat bread and biscuits production by cassava, extruded soy protein and pumpkin powder. Food Nutr. Sci., 6: 660-674.

Anuonye, J. C., A. A. Jigam and G. M. Ndaceko (2012). Effects of extrusion-cooking on the nutrient and anti-nutrient composition of pigeon pea and unripe plantain blends. J. Appl. Pharm. Sci., 2: 158-162.

AOAC (2010). Official Methods of Analysis. $17^{\text {th }}$ edition.Association of Official Analytical Chemists, Washington DC, USA. https://goo.gl/Tj8X2T

Asif-Ul-Alam, S. M., M. Z. Islam, M.M. Hoque and K. Monalis (2014). Effect of drying on the physicochemical and functional properties of green banana (Musa sapientum) flour and development of baked product. Am. J. Food Sci. Technol., 2: 128-133.

Atef, A., E. Abou-Zaid, S. Y. Wafaa and H. Emam (2014). Use of quinoa meal to produce bakery products to celiac and autism stuffs. Int. J. Sci. Res., 3(9): 1344-1354.

Bassinello, P. Z., D. G. C. Freitas, J. L. R. Ascheri, C. Y. Takeiti, R. N. Carvalho, S. N. Koakuzu and A. V. Carvalho (2011). Characterization of biscuits formulated with rice and black bean extruded flours. Procedia Food Sci., 1: 16451652 .

Batista, J. E. R., M. P. de Morais, M. Caliari and M. S. S. Júnior (2016). Physical, microbiological and sensory quality of gluten-free biscuits prepared from rice flour and potato pulp. J. Food Nutr. Res., 55(2): 101-107. 
Bello, F. A., O. J. Ntukidem and B. S. Oladeji (2018). Assessment of chemical compositions, physical and sensory properties of biscuits produced from yellow yam, unripe plantain and pumpkin seed flour blends. Int. J. Food Sci. Nutr. Eng., 8(5): 119-126.

Bolin, H. R. and C. C. Huxsoll (1991). Control of minimally processed carrot (Daucus carotes) surface discoloration caused by abrasion peeling. J. Food Sci., 55: 415-424.

Buera, M. P., C. Petriella and R. D. Lozano (1985). Definition of colour in the non-enzymatic browning. Die Farbe, 33: 316-326.

Chand, N. and A. A. Mihas (2006). Celiac disease: current concepts in diagnosis and treatment. J. Clin. Gastroenterol., 40: 3-14.

Chinma, C. E., B. D. Igbabul and O. O. Omotayo (2012). Quality characteristic of cookies prepared from unripe plantain and defatted sesame flour blend. Am. J. Food Technol., 2: 398-408.

Chinma, C. E., S. James, H. Imam, O. B. Ocheme, J. C. Anuonye and C. M. Yakubu (2011). Physicochemical and sensory properties and invitro digestibility of biscuits made from blends of tigernut (Cyperus esculentus) and pigeon pea (Cajanus cajan). Nig. J. Nutr. Sci., 32: 5562.

Danbaba, N., I. Nkama and H. B. Mamudu (2016). Application of response surface methodology (RSM) for the production and optimization of extruded instant porridge from broken rice fractions blended with cowpea. Int. J. Nutr. Food Sci., 5(2): 105-116.

de Simas, K. N., L. N. Vieira, R. Podesta, C. M. O. Muller, M. A. Vieira, R. C. Beber, M. S. Reis, P. L. M. Barreto, E. R. Amante and R. D. M. C. Amboni (2009) Effect of king palm (Archontophoenix alexandrae) flour incorporation on physicochemical and textural characteristics of gluten-free cookies. Int. J. Food Sci. Technol., 44: 531-538.

De-La Barca, A. M. C., M. E. Rojas-Martinez, A. R. Islas-Rubio and F. Cabrera-Chavez (2010). Gluten-free breads and cookies of raw and popped amaranth flours with attractive technological and nutritional qualities. Plant Foods for Human Nutr., 65: 241- 246.

Dhingra, S. and S. Jood (2001). Organoleptic and nutritional evaluation of wheat breads supplemented with soybean and barley flour. Food Chem., 77: 479-488.

Doporto, M. C., F. Sacco, S. Z. Viña and M. A. García (2017). Quality and technological properties of gluten-free biscuits made with Pachyrhizus ahipa flour as a novel ingredient. Food and Nutr. Sci., 8: 70-83.

ES (Egyptian Standard) (2013). ES-416-1: Biscuits and methods of analysis and testing. Part 1. Egyptian Organization for Standardization and Quality, ARE.

Esteller, M. S. and S. C. S. Lannes (2005). Complementary parameters of requirements to fixing identity and quality of bakery products. Food Sci. Technol. (Campinas), 25: 802-806. In Portuguese.

Fasoyiro, S. B. and K. A. Arowora (2013). Chemical, pasting and sensory properties of whole fermented maize (ogi) fortified with pigeon pea flour. Int. J. Food, Agric. Vet. Agric. Eng., 7: 218-220.

Ikujenlola, V. A. and E. A. Adurotoye (2014). Evaluation of quality characteristics of high nutritious dense complementary food from mixtures of malted quality maize (Zea mays L) and steam cowpea (Vognaun guicalate). J. Food Process Technol., 5: 291.

Javaria, S., A. Karim, M. Waqas, S. Raza, A. Mumtaz and K. Waseem (2017). Formulation and quality evaluation of aglutenics biscuits supplemented with rice bran for coeliac patients. Pure Appl. Biol., 6(4): 1283-1296.

Kaur, M., K. S. Sandhu, A. Arora and A. Sharma (2014). Gluten free biscuits prepared from buckwheat flour by incorporation of various gums: Physicochemical and sensory properties. LWT-Food Science and Technol., 62: 628-632.

Kweon, M., I. Stade, H. Levine, R. Martin and E. Souza (2009). Exploration of sugar functionality in sugar-snap and wire-cut cookie baking: implication for potential sucrose replacement or reduction. Cereal Chem., 86(4): 425-433.

Majzoobi, M., Z. Vosooghi Poor, J. Jamalian and A. Farahnaky (2016). Improvement of the quality of gluten-free sponge cake using different levels and particle sizes of carrot pomace powder. Int. J. Food Sci. Technol., 51: 13691377.

Man, S., A. Paucean and S. Muste (2014). Preparation and quality evaluation of gluten-free biscuits. Bull. UASVM Food Sci. Technol., 71(1): 3941.

Manley, D. (2001). Biscuit, cracker and cookie recipes for the food industry. Cambridge, UK: Woodhead Publishing Limited.

McWatters, K. H., J. B. Ouedraogo, A. V. A. Resurrection, Y. C. Hung and R. D. Phillips (2003). Physical and sensory characteristics of sugar cookies containing mixtures of wheat, fanio (Digitaria exilis) and cowpea (Vigna unguiculata) flours. Int. J. Food Sci. Technol., 38: 403-410.

Meilgaard, M. C., G. V. Civille and B. T. Carr (2007). Sensory evaluation techniques. $4^{\text {th }}$ Edition, CRC Press LLC, New York, USA.

Mishra, A., M. Devi and P. Jha (2015). Development of gluten free biscuits utilizing fruits and starchy vegetable powders. J. Food Sci. Technol., 52(7): 4423-4431.

Morsy, N. E., A. M. Rayan and K. M. Youssef (2015). Physico-chemical properties, antioxidant activity, phytochemicals and sensory evaluation of rice-based extrudates containing dried Corchorus olitorius L. leaves. J. Food Process. Technol., 6: 408. doi:10.4172/21577110.1000408 
Noor, A. A., Y. M. Noor and L. H. Ho (2012). Physicochemical and organoleptic properties of cookies incorporated with legume flour. Int. Food Res. J., 19(4): 1539-1543.

Okpala, L. C. E. and C. Okoli (2011). Nutritional evaluation of cookies produced from pigeon pea, cocoyam and sorghum flour blends. Afr. J. Biotechnol., 10(3): 433-438.

Okudu, H. O. and M. C. Ojinnaka (2018). Nutrients and sensory properties of biscuits produced from sorghum (Sorghum bicolor) and watermelon seed (Citrullus lanatus) flour blends. Direct Res. J. Agric. Food Sci., 6(12): 355-359.

Omoba, O. S. and A. Omogbemile (2013). Physicochemical properties of sorghum biscuits enriched with defatted soy flour. British J. Appl. Sci. Technol., 3(4): 1246-1256.

Pereira, D., P. M. Correia and R. P. Guine (2013). Analysis of the physical-chemical and sensorial properties of Maria type cookies. Acta Chimica Slovaca, 6: 269-280.

Sanni, L. O., A. A. Adebowale and S. O. Tafa (2006). Proximate, functional, pasting and sensory qualities of instant yam flour.14 ${ }^{\text {th }}$ ISTRC symposium, Central Tuber Crops Research Institute, Trivandrum, Kerala State, India.

Sapone, A., J. C. Bai, C. Ciacci, J. Dolinsek, P. H. R. Green and M. Hadjivassiliou (2012). Spectrum of gluten-related disorders: consensus on new nomenclature and classification. BMC Medicine, 10: 1-12.

Sciarini, L. S., G. T. Perez, M. De Lamballerie, A. E. Leon and P. D. Ribotta (2012). Partial-baking process on gluten-free bread: Impact of hydrocolloid addition. Food and Bioprocess Technol., 5: 1724-1732.

Sharoba, A. M., A. M. Abd El-Salam and H. Hoda (2014). Production and evaluation of gluten free biscuits as functional foods for celiac disease patients. J. Agroalimentary Process \& Technologies, 20(3): 202-2014.

Silky, M. P. G. and A. Tiwari (2014). Development of high protein biscuits using pigeon pea broken flour. Int. J. Eng. Innov. Technol., 4: 84-89.

Singh, S. (2008). Development of high protein biscuits from green gram flour manufactures. Applied Science Publisher Ltd., London, UK.

Sozer, N., L. Circerelli, R. L. Heiniaö and K. Poutanen (2014). Effect of wheat bran addition on in vitro starch digestibility, physic-mechanical and sensory properties of biscuits. J. Cereal Sci., 60: 105-113.

Tiwari, B. K., C. S. Brennan, R. Jaganmohan, A. Surabi and K. Alagusundaram (2011). Utilization of pigeon pea (Cajanus cajan L.) byproducts in biscuit manufacture. LWT-Food Sci. Technol., 44: 1533- 1537.

Torres, A., J. Frias, M. Grantito and C. Vidal-Valverde (2007). Germinated Cajanus cajan seeds as ingredients in pasta products: Chemical, biological and sensory evaluation. Food Chem., 101: 202-211.

Trinidad, P. T., A. C. Mallillin, A.S. Loyola, R.S. Sagum and R. R. Encabo (2010). The potential health benefits of legumes as a good source of dietary fibre. British J. Nutr., 103: 567-574.

Tyagi, S. K., M. R. Manikantan, H. S. Oberoi and G. Kaur (2007). Effect of mustard flour incorporation on nutrition, textural and organoleptic characteristics of biscuits. J. Food Eng., 80(4): 1043-1050.

Van Toan, N. and P. T. T. Thanh (2018). Preparation and improved quality production of flour and the made biscuits from the taro. Int. J. Food Sci. Nutr., 3 (5): 71-79.

Vega-Gálvez, A., M. Miranda, J. Vergara, E. Uribe, L. Puente and E. A. Martínez (2010). Nutrition facts and functional potential of quinoa. J. Sci. Food Agric., 90: 2541-2547.

\section{الخصائص الفيزيائية ـ الكيميائية والقابلية العامة للبسكويث الخالي من الجلوتين متأثراً بنوعية بعض دقيق

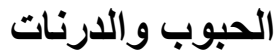

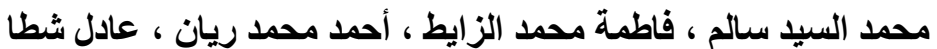

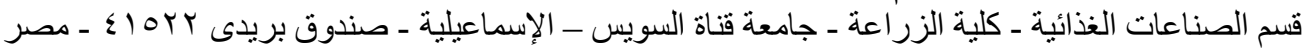

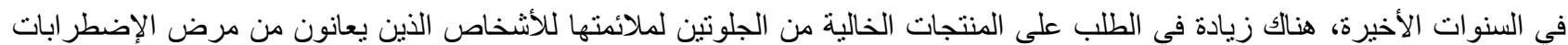

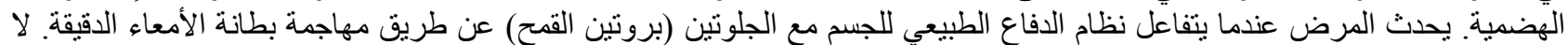

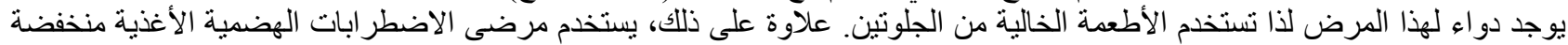

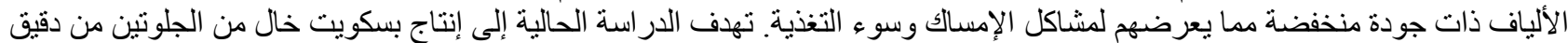

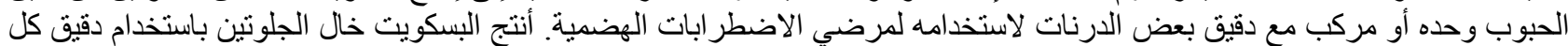

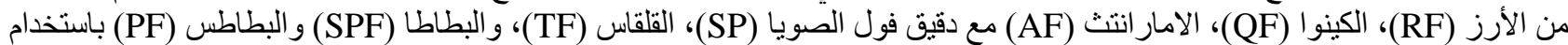

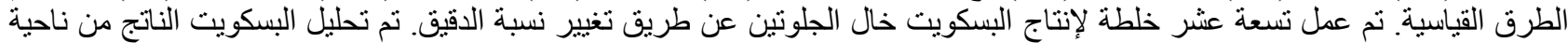

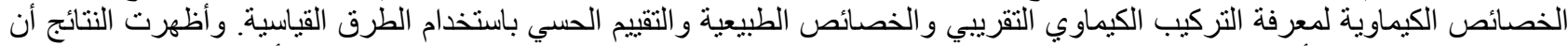

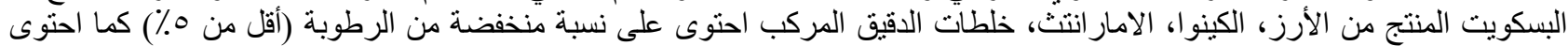

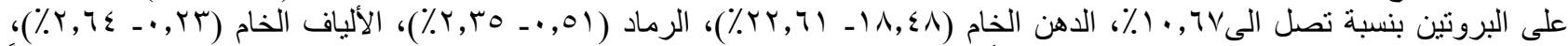

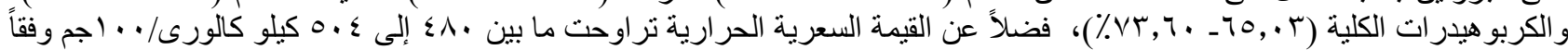

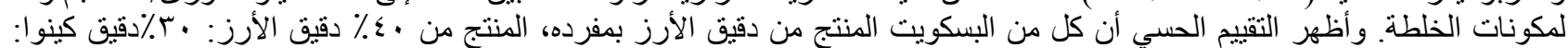

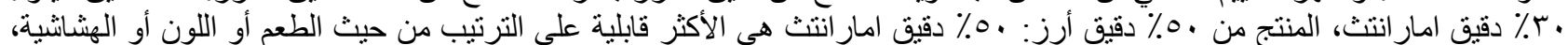

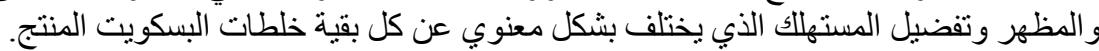

